\title{
Estrutura da sensibilidade moral dos psiquiatras do Brasil*
}

\author{
Moral sensitivity framework on Brazilian psychiatry
}

\author{
Marcos Liboni
}

Liboni M. A Estrutura da sensibilidade moral dos psiquiatras do Brasil [tese]. Saúde, Ética \& Justiça. 2005;10(1/ 2):56-7.

RESUMO: INTRODUÇÃO: A importância da bioética tem uma demanda importante na prática médica e é muito pouco discutida na psiquiatria. Antes de se pensar o panorama bioético do paciente e do contexto de tratamento, deve-se avaliar a postura bioética do profissional envolvido na relação médico-paciente. Como em outras áreas da psicologia e da psiquiatria, o uso de instrumentos de avaliação de atitudes tem se mostrado útil na discussão de várias situações e comportamentos. No campo da relação médico-paciente na psiquiatria, o Questionário de Sensibilidade Moral (QSM), uma escala dimensional com respostas tipo Likert sobre questões éticas (divididas em 6 dimensões propostas para a sensibilidade Moral) na enfermagem e na psiquiatria, mostra-se como um instrumento específico e útil na investigação das atitudes morais do médico. OBJETIVOS: Conhecer a estrutura da sensibilidade moral dos médicos psiquiatras do Brasil. Descrever o panorama das variáveis epidemiológicas e demográficas da população estudada. Investigar as relações de algumas variáveis epidemiológicas (demográficas e culturais) com a estrutura da sensibilidade moral dos médicos psiquiatras do Brasil. MÉTODOS: Comparar estatisticamente os resultados das dimensões da escala com as variáveis epidemiológicas colhidas no momento da avaliação. RESULTADOS: Foram avaliados 522 médicos psiquiatras do Brasil. As variáveis epidemiológicas investigadas foram: a idade, com média de 49 anos, a raça (brancos, $91,60 \%$ ), o sexo (homens, $65,70 \%$ ) e o estado civil (casados, $64,00 \%$ ). Os psiquiatras também foram avaliados com relação a outros aspectos, a saber: religião (católicos, $44,40 \%$ ), ter feito ou não residência médica ( $\operatorname{sim}, 75,10 \%$ ), tipo de prática na psiquiatria (mais que 1 atividade, $86,20 \%$ ) e tempo de prática profissional (21,3 anos). DISCUSSÃO: Houve a concordância total com as dimensões da Sensibilidade Moral como autonomia, respeito pela integridade e relacionamento interpessoal; concordância parcial na benevolência e respeito às regras, e forte discordância na experiência de conflitos éticos. As variáveis demográficas que tiveram relação estatisticamente significativa com as dimensões e questões da escala foram: idade, cor da pele, sexo, estado civil, religião, residência médica como formação profissional, tempo de experiência profissional e tipo de prática na psiquiatria. CONCLUSÃO: O QSM mostrou ser útil como escala de avaliação moral da prática médica psiquiátrica no Brasil. A estrutura da sensibilidade moral dos médicos psiquiatras brasileiros sofre múltiplas influências em sua relação com elementos.

DESCRITORES: Bioética, Ética Médica, Moral, Saúde mental, Desenvolvimento moral.

\footnotetext{
* Tese de doutorado apresentada à Faculdade de Medicina da Universidade de São Paulo. Orientador: Cláudio Cohen
} 
Liboni M. A Estrutura da sensibilidade moral dos psiquiatras do Brasil.

Liboni M. Moral sensitivity framework on Brazilian psychiatry [tese]. Saúde, Ética \& Justiça. 2005;10(1/2):567.

ABSTRACTS: INTRODUCTION: Despite the importance of Bioethics in all fields of medical sciences, it does not receive enough attention, mainly in psychiatry. Before considering the most appropriate approach to treatment, any physician must focus on its bioethical medical-patient relationship. Like other neuroscience areas such as psychology, the use of instruments that evaluate the phenomenology of attitudes have proved to be necessary in many discussions that involve behavior. In regard to the relationship between physician and his patient, the Moral Sensitivity Questionnaire (MSQ), a Likert-type scale with 30 questions concerning 6 dimensions of moral sensitivity in psychiatric practice, has shown itself to be a specific and good selfevaluation instrument that can be used in the investigation of psychiatrists' moral sensitivity attitudes. OBJECTIVE: To know the Brazilian Psychiatrists' Moral Sensitivity framework; and to describe the epidemiology and demographics of the population studied and to investigate some relations within these variables with the Psychiatrists Moral Sensitivity. METHODS: The results and scale domains were compared statistically using the epidemiological variables mentioned in the questionnaire. RESULTS: A number of 522 Brazilian psychiatrists were evaluated. The epidemiological variables were age (average of 49 years old), race $(91,60 \%$ were white), sex $(65,70 \%$ were men), and marital status $(64,00 \%$ were married). The psychiatrists were also evaluated concerning other aspects, namely: religion (44,40\% were Catholic), status of medical residency as field of training $(75,10 \%$ had academic residency training), type of professional practice $(86,20 \%$ had more than one practice field in psychiatry) and length of professional practice (average 21,3 years). DISCUSSION: There was a total agreement in the moral dimensions mentioned in autonomy, respect for integrity and interpersonal relationship. A partial concordance was achieved in benevolence and rules. A strong disagreement was shown in experiencing medical conflicts. The epidemiological variables that were strongly related to the scale dimensions were age, religion, medical residency, length of professional experience and the type of psychiatric practice. CONCLUSION: The QSM has shown to be useful as a bioethical tool in the field of investigation of Brazilian Psychiatrists' Moral Sensitivity. It was also viewed that the Brazilian Psychiatrists' Moral Sensitivity framework can be influenced by epidemiological, demographic and cultural factors.

KEY WORDS: Bioethics, Medical, ethics, Morale, Scales, Mental health, Moral development. 